\title{
Functions and Application of Glomalin-Related Soil Proteins: A Review
}

(Fungsi dan Penggunaan Protein Tanah Berkaitan Glomalin: Suatu Ulasan)

\author{
WEI-QIN GAO, PENG WANG \& QIANG-SHENG WU*
}

\begin{abstract}
Glomalin that is a kind of glycoprotein produced by arbuscular mycorrhizal fungi in the phylum Glomeromycota, has some characteristics of hydrophobins with insolubility and difficulty in its extraction. The protein is highly homologous with heat shock protein 60. In soils, glomalin is measured as glomalin-related soil protein (GRSP). GRSP is highly positively correlated with soil aggregate stability, because it is a new component of soil organic matter. The mycorrhiza-released glomalin has represented potential functioning in soil ecosystems, which include promoting the storage of soil organic carbon, improving the structure of soil aggregates, enhancing the resistance of plants, and reducing the metal toxicity of plants. In addition, some potted and field experiments have been performed to exogenously apply the GRSP in crop plants to confirm the GRSP roles. Hence, GRSP is one of the most significant multidisciplinary topics between fungal physiology and soil biochemistry. Despite much work performed on glomalin from 1996, there are still gaps of GRSP that needs to be solved, including purification, structural features and environmental responses.
\end{abstract}

Keywords: Carbon cycle; drought stress; extraction; mycorrhiza; soil aggregation

\section{ABSTRAK}

Glomalin merupakan sejenis glikoprotein yang dihasilkan oleh kulat mikoriza arbuskel pada filum Glomeromycota, mempunyai ciri-ciri hidrofobin dengan ketidaklarutan dan kesukaran dalam pengekstrakan. Protein adalah sangat homolog dengan protein kejutan haba 60. Dalam tanah, glomalin diukur sebagai protein tanah berkaitan glomalin (GRSP). GRSP adalah sangat positif berkolerasi dengan kestabilan agregat tanah, kerana ia adalah satu komponen baharu jirim tanah organik. Glomalin pelepasan mikoriza telah mewakili potensi berfungsi dalam ekosistem tanah, termasuk menggalakkan penyimpanan karbon organik tanah, memperbaiki struktur agregat tanah, meningkatkan ketahanan tumbuhtumbuhan dan mengurangkan logam ketoksikan tumbuh-tumbuhan. Di samping itu, sesetengah uji kaji tanaman pasu dan lapangan telah dijalankan secara eksogen untuk menggunakan GRSP dalam tanaman tumbuhan untuk mengesahkan peranan GRSP. Oleh itu, GRSP adalah salah satu daripada topik pelbagai disiplin yang paling ketara antara kulat fisiologi dan biokimia tanah. Walaupun banyak kerja yang dilakukan pada glomalin dari tahun 1996, masih terdapat jurang GRSP yang perlu diselesaikan, termasuk penulenan, ciri struktur dan tindak balas alam sekitar.

Kata kunci: Kitaran karbon; mikoriza; pengagregatan tanah; pengekstrakan; tekanan kemarau

\section{INTRODUCTION}

Arbuscular mycorrhizal fungi (AMF), one of soil microorganisms widely distributed in various terrestrial ecosystems can form a symbiotic association with roots of more than $80 \%$ of terrestrial plants (Saha et al. 2014; Zou \& Wu 2011). In general, spores of AMF in the soil germinate, extend and finally form an appressorium to contact with root epidermal cells of host plants (Figure 1). These colonized hyphae continue in developing cortical cells of roots, where arbuscles are formed. The internal hyphae of roots extend outward to form external hyphae on roots, which reside on the root surface for absorbing nutrients and water from the soil. Furthermore, the relationship between AMF and plant roots dramatically modulates the composition, succession and stability of plant community structure (Yao \& Zhu 2010). Arbuscular mycorrhizas have positive effects on plant growth, nutrient absorption, stressed tolerance and soil structure (Chen et al. 2015; Oyewole et al. 2017).

A protein which originates from intraradical hyphae in roots and the surface of extraradical hyphae in the rhizosphere (Figure 1) was firstly found by Wright et al. (1996). The protein of AMF can be released from mycelial surface into soils, named as glomalin. The monoclonal antibody immunofluorescence localisation further confirmed that the protein was actually produced by AMF (Wright et al. 1998). Earlier studies indicated that glomalin concentration in soils was observed to decrease along with the AMF hyphae density (Steinberg \& Rillig 2003). Long-term use of fungicides on grasslands decreased mycorrhizal diversity and colonisation, resulting in the decrease of glomalin in soils (Rillig 2004). Many studies have shown that inoculation of AMF heavily increased the concentration of rhizosphere 
glomalin (Xie et al. 2013; Yang et al. 2017, 2016). The glomalin represents great significance in soil structure and soil organic matter composition, as well as with fungal physiology and soil biochemistry (Zou et al. 2016). Despite much work performed on glomalin from 1996, there are still unknown problems of glomalin that needs to be solved, including purification, structural features and environmental responses. This review mainly focuses on the origin, extraction, classification, potential functioning and application of glomalin (Figure 1).

\section{ORIGIN OF GLOMALIN}

The study of glomalin began with the discovery of a monoclonal antibody (MAb 32B11) that can be immunologically reactive on the surface of spores of Glomus intraradices (Wright et al. 1998, 1996). Based on sodium dodecyl sulfate polyacrylamide gel electrophoresis (SDS-PAGE), Wright et al. (1998) analyzed the difference between the protein produced in this soil and the protein extracted from mycorrhizal mycelium, and found that the bands of the two proteins were the same. The glycoprotein is named as glomalin due to AMF from the Glomales, the taxonomic order (Wright \& Upadhyaya 1996). Glomalin can be originated from intraradical hyphae in roots and the surface of extraradical hyphae in the rhizosphere, and can be released from mycelial surface into soils (Wright et al. 1996). It seems that glomalin is believed to be the only protein directly secreted by AMF into soils (Rillig 2004). In fact, glomalin in soils according to the extraction protocol contains other non-glomalin ingredients (Rillig 2004). As a result, Rillig (2004) proposed a new name, glomalin-related soil protein (GRSP), to replace glomalin in soils (Table 1).

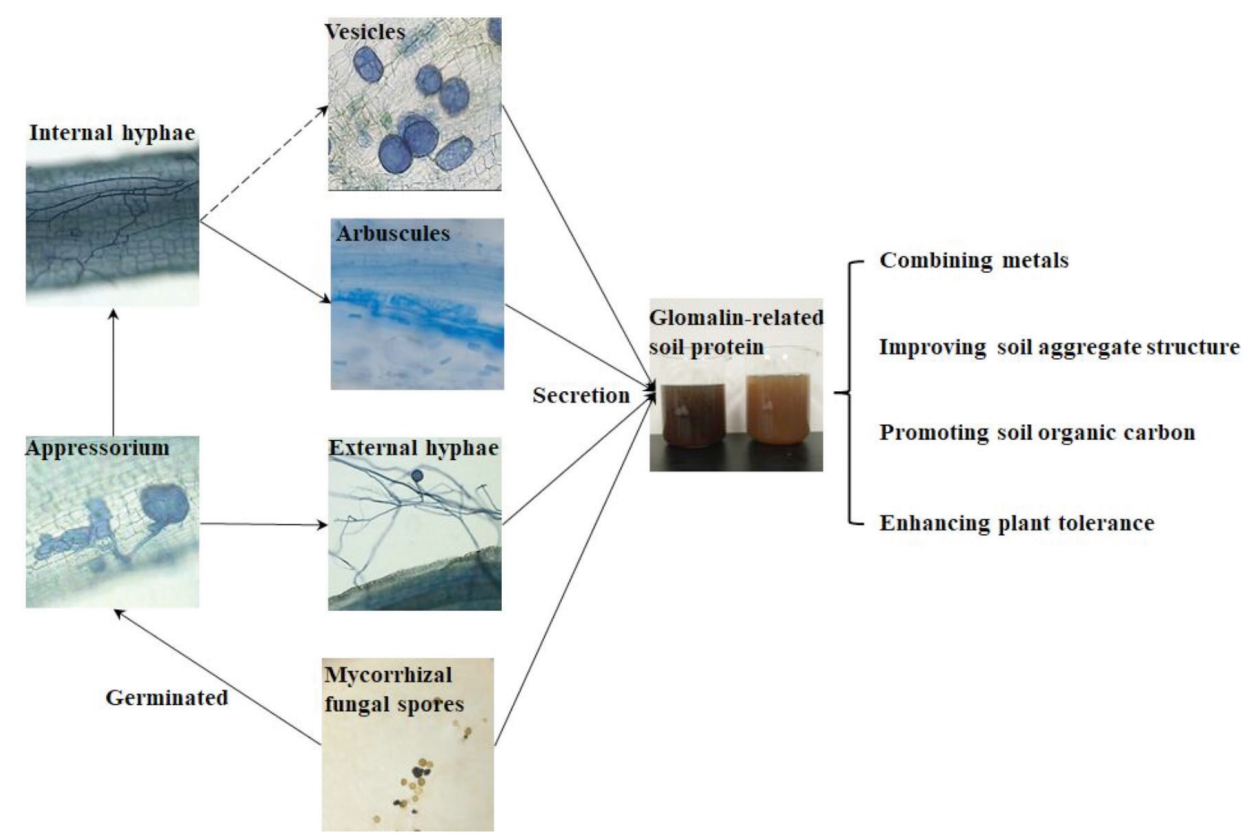

FIGURE 1. The potential functions of glomalin secreted by arbuscular mycorrhizal fungi

TABLE 1. History of the development in glomalin terminology

\begin{tabular}{|c|c|c|}
\hline Times & Proposers & Contributions \\
\hline 1996 & Wright et al. & Finding the special protein from arbuscular mycorrhizal fungi (AMF), and further naming it as glomalin \\
\hline 1998 & Wright et al. & $\begin{array}{l}\text { Using different citric acid buffers to extract the glomalin from the soil and dividing them into easily extractable } \\
\text { glomalin (EEG) and total glomalin (TG), and the part of the immune response that can be associated with } \\
\text { MAb 32B11 is called IREEG and IRTG, respectively }\end{array}$ \\
\hline 2004 & Rillig & $\begin{array}{l}\text { Glomalin-related soil protein (GRSPs) are used to replace glomalin term, and using BRSP (Bradford-reactive } \\
\text { soil protein), IRSP (immunoreactive soil protein), EE-BRSP (easily extractable BRSP) and EE-IRSP (easily } \\
\text { extracted immunoreactive soil protein) to replace the corresponding glomalin terminology before }\end{array}$ \\
\hline 2008 & Rosier et al. & Bradford-root protein, a root-originated glomalin \\
\hline 2013 & Koide and People & GRSPs are divided into the fraction 1 (easily extracted) and the fraction 2 (difficult extracted) \\
\hline 2014 & Wu et al. & $\begin{array}{l}\text { Named the fraction } 2 \text { as difficulty extractable glomalin-related soil protein (DE-GRSP), based on Koide and } \\
\text { People (2013) }\end{array}$ \\
\hline 2016 & Wu et al. & Defined Bradford-root protein as glomalin-related root protein \\
\hline
\end{tabular}


Gadkar and Rillig (2006) further confirmed that GRSP released from Glomus intraradices, defined as Gihsp60, and had high similarity to heat shock protein 60 . Moreover, Gihsp60 encoded a full-length cDNA of 1773 bp length. The open reading frame of Gihsp60 may encode a protein of 590 amino acids and have three introns of 67, 76, and 131 bp length.

\section{EXTRACTION OF GRSP}

At present, the protocol of glomalin extraction is based on Wright et al. (1996). The protocol is as follows: $1 \mathrm{~g}$ of soil samples was mixed with $8 \mathrm{~mL} 50 \mathrm{mmol} / \mathrm{L}$ citrate buffer ( $\mathrm{pH} 8.0)$ for the analysis of total glomalin-related soil protein (T-GRSP) and with $8 \mathrm{~mL} 20 \mathrm{mmol} / \mathrm{L}$ citrate (pH7.0) for the analysis of easily extractable glomalin-related soil protein (EE-GRSP). The mixture was incubated at $121^{\circ} \mathrm{C}$ and $0.11 \mathrm{MPa}$ for $90 \mathrm{~min}$ for T-GRSP and for $30 \mathrm{~min}$ for EE-GRSP, respectively.

Given that EE-GRSP is a component of T-GRSP, they are often strongly correlated with each other. Koide and People (2013) further divided GRSP into fraction 1 and fraction 2. Hereinto, the fraction 1 (corresponding to EEGRSP) was relatively more labile, and the fraction 2 as an older glomalin was more difficult to extract and recalcitrant in soils. Subsequently, Wu et al. (2014a) proposed that the fraction 1 was called as EE-GRSP, and the fraction 2 was defined as difficultly extractable glomalin-related soil protein (DE-GRSP). T-GRSP is the sum of EE-GRSP and DE-GRSP (Wu et al. 2015a). The extraction protocol regarding these GRSPs is shown in Figure 2. Here, DE-GRSP is extracted from the residue remaining from EE-GRSP extraction at $0.11 \mathrm{MPa}$ with $50 \mathrm{mmol} / \mathrm{L}$ citrate $(\mathrm{pH} 8.0)$ for $60 \mathrm{~min}$ and centrifuged at $10,000 \times \mathrm{g}$ for $20 \mathrm{~min}$. In another study conducted by Du et al. (2015), soil sample weight was $0.75 \mathrm{~g}$, and the extracted citrate buffer of EEGRSP should be $6 \mathrm{~mL}$ (corresponding to $1: 8, \mathrm{w} / \mathrm{v}$ ), which can represent the highest EE-GRSP production extracted.

Glomalin can be quantified by either Bradford method (Wright et al. 1996) or MAb32B11-ELISA (Wright \& Upadhyaya 1998, 1996; Wright et al. 1996) assay after the extraction. Meanwhile, Bradford method is widely used to determine the concentration of soil glomalin. As proposed by Rillig et al. (2004), under Bradford method conditions, GRSP can be divided into four categories namely Bradfordreactive soil protein (BRSP), easily extractable BRSP (EE-BRSP), immunoreactive soil protein (IRSP) and easily extracted immunoreactive soil protein (EE-IRSP). Rosier et al. (2006) reported that the extraction of the current program may not completely remove all proteins other than glomalin. In some soils, citrate buffers may extract organic compounds other than protein such as humic acid (Nichols \& Wright 2005; Schindler et al. 2007). The Bradford method is not used to test the soil AMF-secreted glomalin when soil organic matter content is very high. Subsequently, Bolliger et al. (2008) measured the purity of GRSP in a variety of methods including immunochemical, lectin-affinity and soil labeling experiment, in order to re-examine the glomalin-purity with the citrate extractionBradford assay procedure. They found that the main ingredient was still glomalin. On the other hand, larger centrifugal forces may isolate more and tinier particles of the soil, thus raising the purity of GRSP extracted from the soil (Du et al. 2015). However, at present, glomalin is not produced in large quantities according to the restricted techniques. Since the current protocol about glomalin extraction does not exclude the impurities from non-AMF, the extraction protocol needs to be further optimized.

Besides soil GRSP, Rosier et al. (2008) tried to extract Bradford-root protein, a root-originated glomalin. Wu et al. (2016a) further defined it as glomalin-related root protein (GRRP). The protocol of GRRP is as follows: $1 \mathrm{mg}$ of dried root sample was autoclaved with $50 \mathrm{mmol} / \mathrm{L}$ sodium citrate (pH8.0) at $121^{\circ} \mathrm{C}$ for $60 \mathrm{~min}$, and centrifuged at $5000 \times \mathrm{g}$ for $15 \mathrm{~min}$. The supernatant was stored at $4^{\circ} \mathrm{C}$ until analysis. Prior to Bradford and an indirect ELISA with MAb32B11, the supernatant was centrifuged at $10000 \times \mathrm{g}$ for $3 \mathrm{~min}$.

GRSP FUNCTIONING ON SOIL ORGANIC CARBON

Soil organic carbon (SOC) is the important component in global carbon cycle (Tang et al. 2016). AMF itself cannot

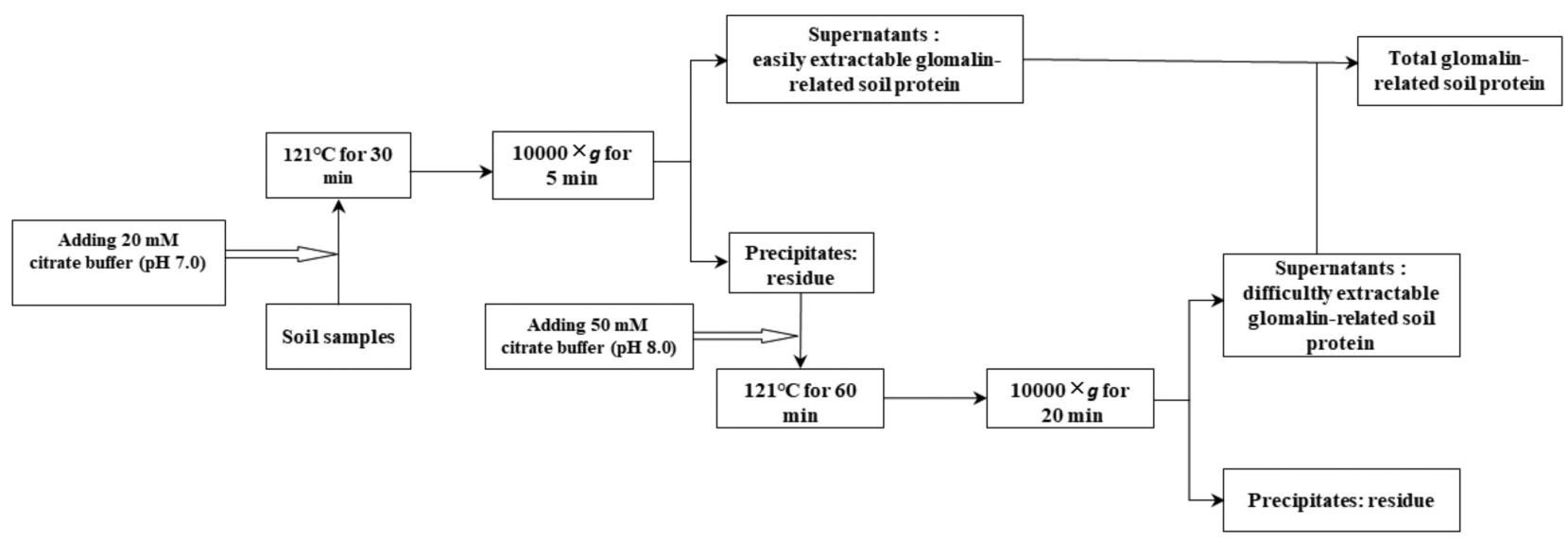

FIGURE 2. The extraction protocol of different glomalin-related soil protein fractions in soils 
perform photosynthesis and they rely on the host plant to provide $20 \%$ of the photosynthetically fixed carbon (C) for its growth and development (Averill et al. 2014; Chen et al. 2015). The $\mathrm{C}$ provided by the host plant can enter into the soil in the form of GRSP, thus, GRSP plays an important role in soil C fixation and cycle (Singh et al. 2017). Kumar et al. (2018) reported that GRSP was the most important source of $\mathrm{C}$ in SOC. Moreover, GRSP has a positive contribution to the soil $\mathrm{C}$ pools in native grasslands for a soil binding agent (Purin et al. 2006). Combined with three kinds of soil samples obtained from the surface soil to the depth of $20 \mathrm{~cm}$, Zhang et al. (2017a) drew a linear correlation between GRSP and SOC. It is estimated that GRSP accounts for $4 \%$ to $5 \%$ of total soil $\mathrm{C}$ source, which was higher than the contribution of microbial biomass $\mathrm{C}$ in Hawaiian soils ( $\mathrm{Wu}$ et al. 2014b). As a consequence, GRSP plays a crucial role in both regulation of SOC and maintenance of soil fertility (Preger et al. 2007). However, in citrus orchards, Wang et al. (2015) analysed soil samples from 0 to $15 \mathrm{~cm}$ depth rhizosphere of four similar citrus trees, and found that there was no significant correlation between SOC and any part of GRSPs. It seems that GRSP may not provide a positive contribution to the SOC pool. Recently, the chemical structure of GRSP was shown by the method of the solid-state ${ }^{13} \mathrm{C}$ cross polarisation magic angle spinning (Zhang et al. 2017a). The result showed that GRSP had a high carboxyl $\mathrm{C}$ ratio ( $40 \%$ of total content) and relatively high aromatic hydrocarbon ratio (30\% of total content) and alkyl C (20\% of total content). As a result, GRSP could directly promote the SOC accumulation as it retains the number of C (Zhang et al. 2017a). According to its sticky nature and the forms in soil of GRSPS (Dai et al. 2015), GRSPs in the soil have 6 to 42 years of long turnover period (Wu et al.2013), suggesting that GRSPs retain a stubborn structure of organic $\mathrm{C}$ in soils, and indirectly affects SOC (Zhang et al. 2017a). In short, GRSP is beneficial to the accumulation and the circulation of SOC in soils.

\section{GRSP FUNCTIONING ON SOIL AGGREGATE STABILITY}

Soil aggregation is an important and complex process in soil ecosystems (Wu et al. 2016b), which relies on soil microbes to provide adhesive effects on soil particles together (Singh et al. 2012). This process is highly dependent on the formation and stability of soil aggregates (Rillig et al. 2015). Soil aggregate stability plays an important role in soil quality, which protects soil organic materials from microbial decomposition (Bronick \& Lal 2005) and also prevents the degradation of soil structure (Guo et al. 2017). AMF are considered to stabilise soil aggregates, because mycelium and GRSP of AMF have a positive correlation with soil aggregate stability in natural systems (Singh et al. 2012; Xu et al. 2013; Zhang et al. 2017b). In a citrus orchard, both soil EE-GRSP and T-GRSP collectively were significantly and positively correlated with mean weight diameter (MWD, an indicator of soil aggregate stability) (Wu et al. 2014b).
The path model analysis showed that the direct effect of GRSPs on soil aggregate stability was higher than the total (direct and indirect) effect of mycorrhizal hyphae (Rillig et al. 2002). On the one hand, GRSPs stabilise the macroaggregates $(>0.25 \mathrm{~mm})$ to improve soil structure through their glue function (Gadkar \& Rillig 2006), and the function is more significant under drought stress than under salt stress (Zou et al. 2014). On the other hand, GRSPs can reduce water loss within soil aggregates under drought stress as they seem to form a hydrophobic layer on the soil aggregate surface (Nichols 2008). In addition, large polymers can be formed from fine soil particles as GRSPs can cement the polymers in the diameter of $<0.25$ $\mathrm{mm}$ size to finally stabilize soil unit (Borie et al. 2008). In short, GRSPs can bind differently sized soil aggregates to enhance soil stability for storing water or improving soil physical and chemical properties.

\section{GRSP FUNCTIONING ON SOIL TOXIC ELEMENTS}

Toxic metals accumulate in the soil, which negatively affects plant growth and crop yield and even harms human health through enlarged food chain (Kumar et al. 2013). Toxic metals are related to the behavior of plants in the soil and their bioavailability (Huang et al. 2018). AMF are critical to the establishment of sites and the adaptability of plants in serious destruction (Bedini et al. 2010), including soils contaminated by toxic metals (Vallino et al. 2006). AMF reduce the toxicity of toxic metals to plants by converting, accumulating and transferring them (Meier et al. 2012). Under Cd treatments, the concentration of GRSPs was significantly increased by low concentration of $\mathrm{Cd}$ treatment, but notably declined under high concentration of Cd treatment, indicating that GRSPs may have a filtering effect on toxic metals, at least Cd (Xie et al. 2013). Xu et al. (2012) found that root total glomalin content of Sophora viciifolia was increased with the increase of soil $\mathrm{Pb}$ concentration under mycorrhizal conditions, indicating that AMF alleviate $\mathrm{Pb}$ stress by adsorption of GRSPs. It seems that GRSPs have the buffer capacity on toxic metal release to protect the host plant (Wang et al. 2010). Rillig (2004) proposed that GRSPs secreted by AMF had a high binding capacity for certain toxic metals $(\mathrm{Cu}, \mathrm{Cd}$ and $\mathrm{Pb})$. Possibly, GRSPs can stabilise toxic metals and reduce the availability of toxic metals, thereby reducing the impact of toxic metals on other soil microorganisms and plants. In addition, GRSP can combine $\mathrm{Cu}, \mathrm{Ni}, \mathrm{Pb}$ and $\mathrm{Co}$ by $2.3 \%$, $0.83 \%, 0.24 \%$ and $0.24 \%$, respectively, thus reducing the bioavailability of toxic elements (Rillig 2004). Wu et al. (2014) also proved that GRSP could bind $\mathrm{Pb}$ and $\mathrm{Cd}$ in the soil. Hence, GRSPS represent the functioning on mitigating stressed damage of contaminated soils to plants (Vodnik et al. 2008).

\section{GRSP FUNCTION IN ENHANCING PLANT TOLERANCE}

The amino acid sequence of glomalin is homologous with heat shock protein 60 (Hsp60), as shown by liquid 
chromatography-mass spectrometry (Gadkar \& Rillig 2006). It is known that Hsp60 is a protein produced by eukaryotic cells or prokaryotic cells under environmental stress (Chen et al. 2015). The expression of Hsp60 gene can reduce the damage caused by environmental stresses (Kumar et al. 2015). Mycorrhizas under stressed conditions secrete a certain amount of glomalin to protect host plants by serving as a stress-induced protein (Chi et al. 2018; Driver et al. 2005). Under drought stress, AMF could enhance the resistance of trifoliate orange colonised by Funneliformis mosseae and Diversispora versiformis, based on the increase in soil GRSP (Wu et al. 2008). In addition, GRSPs can prevent the loss of water from soils (Zou et al. 2014), thereby, fighting unfavourable environments. Nichols (2008) reported that GRSPs helped host plants to mitigate the adverse effects of drought stress on plants by promoting soil aggregate stability. Hammer and Rillig (2011) also reported that GRSP content in soils was significantly increased under salt stress, which is associated with salt tolerance of host plants. Recently, Chi et al. (2018) extracted EE-GRSP solution from citrus soils and applied onto potted trifoliate orange seedlings. They observed that exogenous EE-GRSP heavily enhanced drought tolerance of trifoliate orange, in terms of changes in antioxidant enzymes, plant growth and soil structure. Possibly, GRSP contains Fe and also binds $\mathrm{Cu}, \mathrm{Mn}$. Hence, exogenous EE-GRSP strongly stimulated leaf FeSOD activity and root $\mathrm{Mn}-\mathrm{SOD}, \mathrm{Cu} / \mathrm{Zn}$-SOD and $\mathrm{Fe}-\mathrm{SOD}$ activities under drought stress (Chi et al. 2018).

On the other hand, in temperate forests, GRSP contained 4.2 to $7.5 \%$ of $\mathrm{Al}$ in the acidic soil (Seguel et al. 2013). As reported by Aguilera et al. (2012), Al could be isolated from GRSP particles to prevent $\mathrm{Al}$ from toxic damage in plants. These results manifest that GRSPs can enhance the resistance of plants to Al stress. However, the production of GRSPs is decreased by the increase of AMF growing space (Rillig \& Steinberg 2002). It is suggested that the glomalin secreted by AMF may be only just for protecting itself, and the functional roles of glomalin in soils are secondary (Purin \& Rillig 2008).

\section{EXOGENOUS GRSP APPLICATION IN CROPS}

The functions of GRSP are gradually recognised and accepted by earlier studies. To confirm GRSP functioning, $\mathrm{Wu}$ et al. extracted and applied EE-GRSP solution in citrus plants under potted condition or in fields (Chi et al. 2018; Wang et al. 2015; Wu et al. 2015b), as shown in Table 2. Wang et al. (2015) applied the EE-GRSP extracted from the citrus orchard soil onto potted trifoliate orange seedlings. The results showed that plant growth was promoted by exogenous EE-GRSP application, dependent on the concentration of exogenous EE-GRSP. Meanwhile, 1/2 strength EE-GRSP exhibited the best effects. In addition, Wu et al. (2015b) applied EE-GRSP solutions into the rhizosphere of 27-year-old Satsuma mandarin grafted on
Poncirus trifoliata and found that exogenous EE-GRSP applications had a significantly positive effect on inducing the production of endogenous EE-GRSP, DE-GRSP and T-GRSP and SOC. Furthermore, exogenous GRSP functions in enhancing soil aggregate stability and soil phosphatase activity (Wu et al. 2015b). Soil tillage heavily disrupts mycorrhizal hyphal network, which had an adverse effect on GRSP production, subsequently weakening the GRSP functioning on aggregate stabilization. As described previously, exogenous EE-GRSP had a positive effect on enhancing drought tolerance of trifoliate orange, due to glomalin behaving as a humic-like substance to stimulate plant growth, as a homologous substance with Hsp60 like a stress moderator, as a hydrophobic layer on fungal hyphae to prevent loss of water, and as a Fe-contained substance to increase plant Fe-SOD activity (Chi et al. 2018). In short, exogenous EE-GRSP seems to be used as an effective regulator in plants and soils to affect soil fertility, soil structure, plant growth and plant tolerance. More studies need to be performed to confirm the roles of exogenous EE-GRSP on field crops, besides citrus plants.

\section{FUTURE PERSPECTIVE}

In short, GRSPs are beneficial to the accumulation and the circulation of SOC. GRSPs can glue soil aggregates to enhance the stability and can adsorb toxic metals in the soil to decrease the damage of toxic metals on plants. In addition, GRSPs partly alleviate negative effects of abiotic stresses, including drought stress and salt stress. Even so, there are still plenty of gaps in this research topic. The structure of glomalin is still vague and it can only be defined as a related soil protein. Hence, future studies still need to analyse the structure and constituents of glomalin. Next, the extraction protocol of glomalin needs to be optimised. At present, the extraction protocol does not exclude some non-relevant impurities, which hinder the identification of glomalin. In addition, the mechanisms regarding the GRSP function in enhancing stressed tolerance need to be clarified. Therefore, more attention needs to be paid on the function of root glomalin. More field experiments regarding exogenous GRSP application should be conducted. Until now, there are three reports about exogenous GRSP application in citrus plants. Other crop plants must be tested regarding their responses to exogenous GRSP. In addition, exogenous DE-GRSP and T-GRSP need to be considered in crops and compared with exogenous EE-GRSP.

\section{ACKNOWLEDGEMENTS}

This study was supported by the Plan in Scientific and Technological Innovation Team of Outstanding Young Scientist, Hubei Provincial Department of Education (T201604) and the National Natural Science Foundation of China (31372017). 


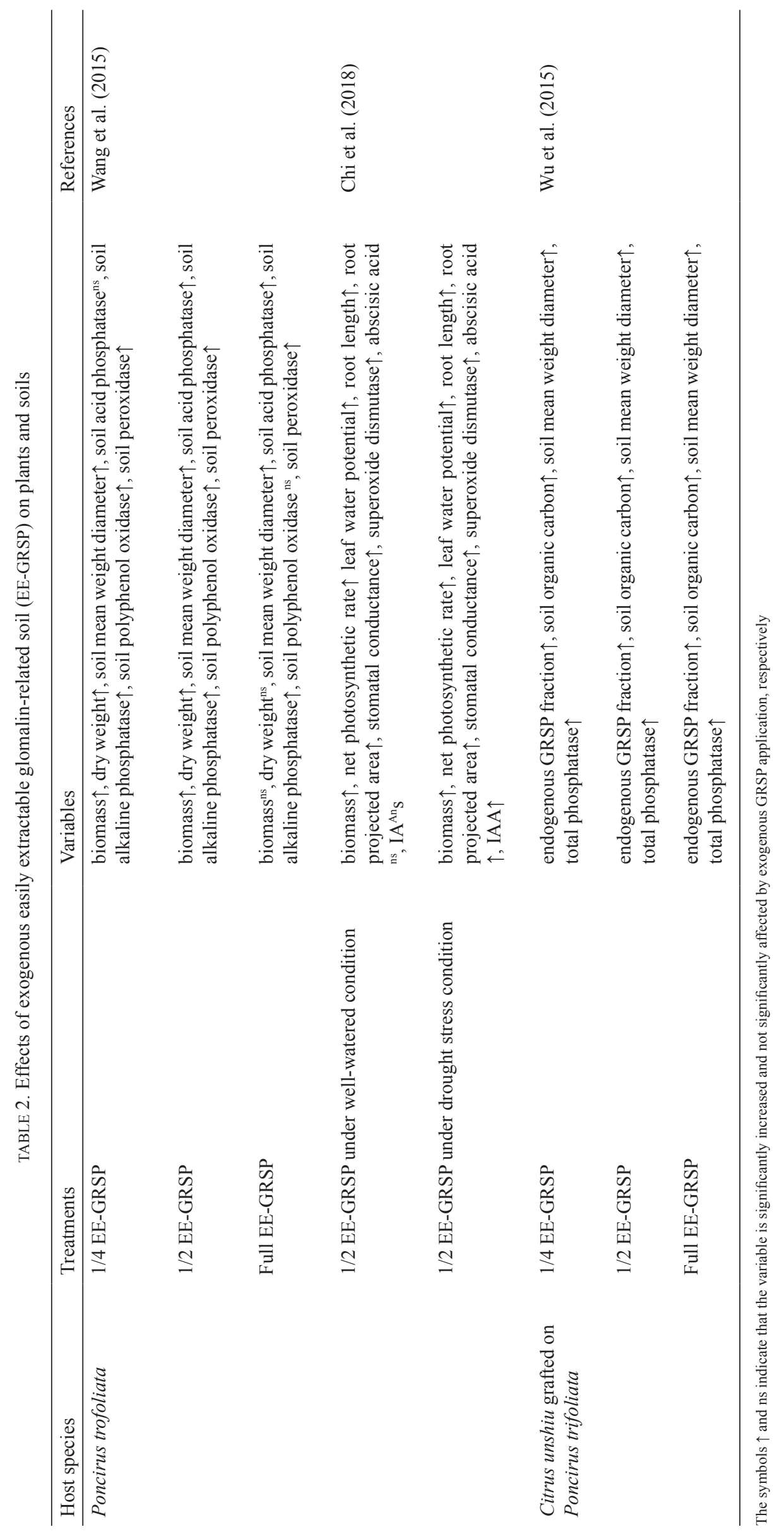




\section{REFERENCES}

Aguilera, P., Borie,F., Seguel,A.\& Cornejo, P. 2012. Fluorescence detection of aluminum in arbuscular mycorrhizal fungal structures and glomalin using confocal laser scanning microscopy. Soil Biology and Biochemistry 43: 2427-2431.

Averill, C., Turner,B.L.\& Finzi, A.C. 2014. Mycorrhiza-mediated competition between plants and decomposers drives soil carbon storage. Nature 505: 543-545.

Bedini, S. 2010. Molecular characterization and glomalin production of arbuscular mycorrhizal fungi colonizing a heavy metal polluted ash disposal island, downtown Venice. Soil Biology and Biochemistry 42: 758-765.

Bolliger,A., Nalla,A., Magid, J.,Ade, N., Nalla,A.D.\& Boghansen, T.C. 2008. Re-examining the glomalin-purity of glomalinrelated soil protein fractions through immunochemical, lectin-affinity and soil labelling experiments. Soil Biology and Biochemistry 40: 887-893.

Borie, F., Rubio, R. \& Morales, A. 2008. Arbuscular mycorrhizal fungi and soil aggregation. Journal of Soil Science and Plant Nutrition 8: 9-18.

Bronick, C.J. \& Lal, R. 2005. Soil structure and management: A review. Geoderma 124: 3-22.

Chen, Y.T., Xu, Y., Ji, D.H., Chen, C.S. \& Xie, C.T. 2015. Cloning and expression analysis of two small heat shock protein (sHsp) genes from Pyropia haitanensis. Journal of Fisheries of China 39: 182-192.

Chi, G.G., Srivastava, A.K. \& Wu, Q.S. 2018. Exogenous easily extractable glomalin-related soil protein improves drought tolerance of trifoliate orange. Archives of Agronomy and Soil Science 64: 1341-1350.

Dai, J., Hu, J.L., Zhu, A.N., Bai, J.F., Wang, J.H. \& Lin, X.G. 2015. No tillage enhances arbuscular mycorrhizal fungal population, glomalin-related soil protein content, and organic carbon accumulation in soil macroaggregates. Journal of Soils and Sediments 15: 1055-1062.

Driver, J.D., Holben, W.E. \& Rillig, M.C. 2005. Characterization of glomalin as a hyphal wall component of arbuscular mycorrhizal fungi. Soil Biology and Biochemistry 37: 101106.

Du, P., Srivastava, A.K., Liu, C.Y., Chen, F. \& Wu, Q.S. 2015. Optimization of glomalin-related soil protein extraction in soil of citrus (Citrus species) orchard. Current Horticulture 3: 3-6.

Gadkar, V. \& Rillig, M.C. 2006. The arbuscular mycorrhizal fungal protein glomalin is a putative homolog of heat shock protein 60. FEMS Microbiology Letters 263: 93-101.

Guo, Y.N., Zou, Y.L. \& He, X.L. 2017. Study on the correlation between colonization of arbuscular mycorrhiza fungi and glomalin and soil factors in Ammopiptanthus mongolicus. China Sciencepaper 12: 1030-1037.

Hammer, E.C. \& Rillig, M.C. 2011. The influence of different stresses on glomalin levels in an arbuscular mycorrhizal fungus-salinity increases glomalin content. PLoS One 6: e28426.

Huang, X.G., Li, S.X., Liu, F.J. \& Lan, W.R. 2018. Regulated effects of Prorocentrum donghaiense Lu exudate on nickel bioavailability when cultured with different nitrogen sources. Chemosphere 197: 57-64.

Koide, R.T. \& People, M.S. 2013. Behavior of Bradford-reactive substances is consistent with predictions for glomalin. Applied Soil Ecology 63: 8-14.

Kumar, A., Ashraf, S., Goud, T.S., Grewal, A., Singh, S.V., Yadav, B.R. \& Upadhyay, R.C. 2015. Expression profiling of major heat shock protein genes during different seasons in cattle
(Bos indicus) and buffalo (Bubalus bubalis) under tropical climatic condition. Journal of Thermal Biology 51: 55-64.

Kumar, S., Singh, A.K. \& Ghosh, P. 2018. Distribution of soil organic carbon and glomalin related soil protein in reclaimed coal mine-land chronosequence under tropical condition. Science of the Total Environment 625: 1341-1350.

Kumar, V. \& Chopra, A.K. 2013. Distribution, enrichment and accumulation of heavy metals in soil and Trigonella foenumgraecum L. (Fenugreek) after fertigation with paper mill effluent. Open Journal of Metal 3: 8-20.

Meier, S., Borie,F., Bolan, N.\& Cornejo,P.2012.Phytoremediation of metal-polluted soils by arbuscular mycorrhizal fungi. Critical Reviews in Environmental Science and Technology 42: 741-775.

Nichols, K.A. 2008. Indirect contributions of AM fungi and soil aggregation to plant growth and protection. In Mycorrhizae: Sustainable Agriculture and Forestry, edited by Siddiqui, Z.A.,Akhtar, S. \& Futai, K. Springer: Dordrecht. pp. 177-194.

Nichols, K.A. \& Wright, S.F. 2005. Comparison of glomalin and humic acid in eight native U.S. Soils. Soil Science 170: 985-997.

Oyewole, B.O., Olawuyi, O.J., Odebode, A.C. \& Abiala, M.A. 2017. Influence of arbuscular mycorrhiza fungi (AMF) on drought tolerance and charcoal rot disease of cowpea. Biotechnology Reports 14: 8-15.

Preger, A.C., Rillig, M.C., Johns, A.R., Du Preez, C.C., Lobe, I. \& Amelung, W. 2007. Losses of glomalin-related soil protein under prolonged arable cropping: A chronosequence study in sandy soils of the South African Highveld. Soil Biology and Biochemistry 39(2): 445-453.

Purin, S. \& Rillig, M.C. 2008. The arbuscular mycorrhizal fungal protein glomalin: Limitations, progress, and a new hypothesis for its function. Pedobiologia 51: 123-130.

Purin, S., Filho, O.K. \& Sturmer, S.L. 2006. Mycorrhizae activity and diversity in conventional and organic apple orchards from Brazil. Soil Biology and Biochemistry 38: 1831-1839.

Rillig, M.C. 2004. Arbuscular mycorrhizae, glomalin, and soil aggregation. Canadian Journal of Soil Science 84: 355-363.

Rillig, M.C. \& Steinberg, P.D. 2002. Glomalin production by an arbuscular mycorrhizal fungus: A mechanism of habitat modification. Soil Biology and Biochemistry 34: 1371-1374.

Rillig, M.C., Trigueros, C.A., Bergmann, J., Verbruggen, E., Veresoglou, S.D. \& Lehmann, A. 2015. Plant root and mycorrhizal fungal traits for understanding soil aggregation. New Phytologist 205: 1385-1388.

Rillig, M.C., Wright, S.F. \& Eviner, V.T. 2002. The role of arbuscular mycorrhizal fungi and glomalin in soil aggregation: Comparing effects of five plant species. Plant and Soil 238: 325-333.

Rosier, C.L., Piotrowski, J.S., Hoye, A.T. \& Rillig, M.C. 2008. Intraradical protein and glomalin as a tool for quantifying arbuscular mycorrhizal root colonization. Pedobiologia 52: 41-50.

Rosier, C.L., Hoye, A.T. \& Rillig, M.C. 2006. Glomalinrelated soil protein: Assessment of current detection and quantification tools. Soil Biology and Biochemistry 38: 2205-2211.

Saha, R., Mondal, B. \& Naskar, B. 2014. AMF inoculation changes, the root development pattern of plants at early stage of colonization. International Journal of Bioresource Science 1: 43-47. 
Schindler, F.V., Mercer, E.J. \& Rice, J.A. 2007. Chemical characteristics of glomalin-related soil protein (GRSP) extracted from soils of varying organic matter content. Soil Biology and Biochemistry 39: 320-329.

Seguel, A., Cumming, J.R., Klugh-Stewart, K., Cornejo, P. \& Borie, F. 2013. The role of arbuscular mycorrhizas in decreasing aluminium phytotoxicity in acidic soils: A review. Mycorrhiza 23(3): 167-183.

Singh, A.K., Rai, A., Pandey, V. \& Singh, N. 2017. Contribution of glomalin to dissolve organic carbon under different land uses and seasonality in dry tropics. Journal of Environmental Management 192: 142-149.

Singh, P.K. 2012. Role of glomalin related soil protein produced by arbuscular mycorrhizal fungi: A review. Agricultural Science Research Journal 2: 119-125.

Steinberg, P.D. \& Rillig, M.C. 2003. Differential decomposition of arbuscular mycorrhizal fungal hyphae and glomalin. Soil Biology and Biochemistry 35: 191-194.

Tang, P.H., Dang, K.L., Wang, L.H. \& Ma, J. 2016. Factors affecting soil organic carbon density in betula albo-sinensis forests on the southern slope of the Ginling Mountains. Acta Ecologica Sinica 36: 1030-1039.

Vallino, M., Massa, N., Lumini, E., Bianciotto, V., Berta, G. \& Bonfante, P. 2006. Assessment of arbuscular mycorrhizal fungal diversity in roots of Solidago gigantea growing in a polluted soil in Northern Italy. Environmental Microbiology 8: 971-983.

Vodnik, D., Grčman, H., Maček, I., Van Elteren, J.T. \& Kovačevič, M. 2008. The contribution of glomalin-related soil protein to $\mathrm{Pb}$ and $\mathrm{Zn}$ sequestration in polluted soil. Science of the Total Environment 392: 130-136.

Wang, M.Y., Xia, R.X. \& Wang, P. 2010. Effects of arbuscular mycorrhizal fungi on available iron and metals sequestered by glomalin in different rhizospheric soil of Poncirus trifoliata. Journal of Fujian Agriculture and Forestry University (Natural Science Edition) 39: 42-46.

Wang, S. \& Wu, Q.S. 2015. Distribution of glomalin-related soil protein and soil organic carbon in water-stable aggregate fractions of citrus rhizosphere. BioTechnology: An Indian Journal 11: 14-17.

Wang, S., Wu, Q.S. \& He, X.H. 2015. Exogenous easily extractable glomalin-related soil protein promotes soil aggregation, relevant soil enzyme activities and plant growth in trifoliate orange. Plant Soil and Environment 61: 66-71.

Wright, S.F., Upadhyaya, A. \& Buyer, J.S. 1998. Comparison of N-linked oligosaccharides of glomalin from arbuscular mycorrhizal fungi and soils by capillary electrophoresis. Soil Biology and Biochemistry 30: 1853-1857.

Wright, S.F., Franke-Snyder, M., Morton, J.B. \& Upadhyaya, A. 1996. Time-course study andpartial characterization of a protein on hyphae of arbuscular mycorrhizal fungi during active colonization of roots. Plant and Soil 181: 193-203.

Wright, S.F. \& Upadhyaya, A. 1998. A survey of soils for aggregate stability and glomalin, a glycoprotein produced by hyphae of arbuscular mycorrhizal fungi. Plant and Soil 198: 97-107.

Wright, S.F. \& Upadhyaya, A. 1996. Extraction of an abundant and unusual protein from soil and comparison with hyphal protein of arbuscular mycorrhizal fungi. Soil Science 161: 575-586.

Wu, Q.S., Srivastava, A.K. \& Cao, M.Q. 2016a. Systematicness of glomalin in roots and mycorrhizosphere of a split-root trifoliate orange. Plant Soil and Environment 62: 508-514.
Wu, Q.S., Wang, S. \& Srivastava, A.K. 2016b. Mycorrhizal hyphal disruption induces changes in plant growth, glomalinrelated soil protein and soil aggregation of trifoliate orange in a core system. Soil and Tillage Research 160: 82-91.

Wu, Q.S., Li, Y., Zou, Y.N. \& He, X.H. 2015a. Arbuscular mycorrhiza mediates glomalin-related soil protein production and soil enzyme activities in the rhizosphere of trifoliate orange grown under different P levels. Mycorrhiza 25: 121-130.

Wu, Q.S., Srivastava, A.K., Wang, S. \& Zeng, J.X. 2015 b. Exogenous application of EE-GRSP and changes in citrus rhizosphere properties. Indian Journal of Agricultural Sciences 85: 802-806.

Wu, Q.S., Cao, M.Q., Zou, Y.N. \& He, X.H. 2014a. Direct and indirect effects of glomalin, mycorrhizal hyphae, and roots on aggregate stability in rhizosphere of trifoliate orange. Scientific Reports 4: 5823.

Wu, Q.S., Huang, Y.M., Li, Y. \& He, X.H. 2014b. Contribution of arbuscular mycorrhizas to glomalin-related soil protein, soil organic carbon and aggregate stability in citrus rhizosphere. International Journal of Agriculture and Biology 16: 207-212.

Wu, Q.S., Xia, R.X. \& Zou, Y.N. 2008. Improved soil structure and citrus growth after inoculation with three arbuscular mycorrhizal fungi under drought stress. European Journal of Soil Biology 44: 122-128.

Wu, Z.P., McGrouther, K., Huang, J.D., Wu, P.B., Wu, W.D. \& Wang, H.L. 2014. Decomposition and the contribution of glomalin-related soil protein (GRSP) in heavy metal sequestration: Field experiment. Soil Biology and Biochemistry 68: 283-290.

Wu, Z.P., Huang, J.D., Wu, P.B.\& Wu, W.D. 2013. Decomposition of glomalin-related soil protein and its correlations with soil characteristics on the basis of a field experiment. Guangdong Agricultural Sciences 40: 65-67.

Xie, X.Y., Weng, B.S., Zhao, S.Z. \& Yan, C.L. 2013. Effects of arbuscular mycorrhizal inoculation and Cd stress on the growth and antioxidant enzyme system of Kandelia obovata. Journal of Xiamen University 52: 244-253.

Xu, J. \& Tang, M. 2013. Relationship between arbuscular mycorrhizal fungi and soil factors in the rhizosphere of different tree species in $\mathrm{Pb}-\mathrm{Zn}$ polluted mine. Journal of Northwest Agriculture and Forestry University 41: 75-80.

Xu, Z.Y., Tang, M., Chen, H., Ban, Y.H. \& Zhang, H.H. 2012. Microbial community structure in the rhizosphere of Sophora viciifolia grown at a lead and zinc mine of northwest China. Science of the Total Environment 453: 435-436.

Yang, Y., He, C., Huang, L., Ban, Y. \& Tang, M. 2017. The effects of arbuscular mycorrhizal fungi on glomalin-related soil protein distribution, aggregate stability and their relationships with soil properties at different soil depths in lead-zinc contaminated area. PLoS ONE 12: e0182264.

Yang, Z.Y., Zong, J., Zhu, X.Z. \& Ling, W.T. 2016. Correlations of glomalin contents and PAHs removal in alfalfa-vegetated soils with inoculation of arbuscular mycorrhizal fungi. Journal of Agro-Environment Science 33: 349-354.

Yao, Q. \& Zhu, H.H. 2010. Arbuscular mycorrhizal fungi: A belowground regulator of plant diversity in grasslands and the hidden mechanisms. In Grassland Biodiversity-Habitat Types, Ecological Processes and Environmental Impacts, edited by Runas, J. \& Dahlgren, T. New York: Nova Science Publisher. pp. 1-14.

Zhang, J., Tang, X.L., Zhong, S.Y., Yin, G.C., Gao, Y.F. \& He, X.H. 2017a. Recalcitrant carbon components in glomalin- 
related soil protein facilitate soil organic carbon preservation in tropical forests. Scientific Reports 7: 2391.

Zhang, Z.H., Wang, Q., Wang, H., Nie, S. \& Liang, Z.W. 2017 b. Effects of soil salinity on the content, composition, and ion binding capacity of glomalin-related soil protein (GRSP). Science of the Total Environment 581: 657-665.

Zou, Y.N., Srivastava, A.K. \& Wu, Q.S. 2016. Glomalin: A potential soil conditioner for perennial fruits. International Journal of Agriculture and Biology 18: 293-297.

Zou, Y.N., Srivastava, A.K., Wu, Q.S. \& Huang, Y.M. 2014. Glomalin-related soil protein and water relations in mycorrhizal citrus (Citrus tangerina) during soil water deficit. Archives of Agronomy and Soil Science 60: 1103-1114.

Zou, Y.N. \& Wu, Q.S. 2011. Efficiencies of five arbuscular mycorrhizal fungi in alleviating salt stress of trifoliate orange. International Journal of Agriculture and Biology 13: 991-995.
Peng Wang

Institute of Citrus Research

Zhejiang Academy of Agricultural Sciences

Taizhou 318026

China

Qiang-Sheng $\mathrm{Wu}^{*}$

Department of Chemistry

Faculty of Science

University of Hradec Kralove

Hradec Kralove 50003

Czech Republic

*Corresponding author; email: wuqiangsh@163.com

Received: 12 May 2018

Accepted: 10 September 2018

Wei-Qin Gao \& Qiang-Sheng Wu*

College of Horticulture and Gardening

Yangtze University

Jingzhou, Hubei 434025

China 